\title{
Gender Differences in First Jobs for New US PhDs in the Mathematical Sciences
}

\author{
by Marie A. Vitulli
}

\section{Communicated by Harriet Pollatsek}

ABSTRACT. Among all US-earned PhDs in mathematics, women have slightly lower initial unemployment rates than men, but their first post-PhD jobs are less likely than men's to be at top universities and in business or industry, despite the prestige of their PhD-granting department. Among non-US-citizens, women have higher unemployment rates during 2001-2015. The percentage of women new PhDs who were employed at bachelor's-only departments was much higher than for men, with the greatest difference occurring in 2012-2015.

We take a long-term look at employment trends for new doctorates with an eye towards gender, citizenship, and gender $\times$ citizenship $^{1}$ differences by analyzing data from the 1991-2015 AMS-ASA-IMS-MAA-SIAM Annual Surveys of the Mathematical Sciences [1].2

We will see that the same differences that Flahive and the current author observed in previous studies in 1997 and 2010 [3] continue today, namely that women were initially employed at academic institutions whose highest degree in mathematics is a bachelor's degree at a substantially higher rate than men, and men were initially employed in business and industry at a considerably higher rate than women.

From 1991-2015 women received about 29\% of the mathematics doctorates from US departments, a bit higher more recently for non-US citizens, as shown in Table 1. During this period US citizens received $46 \%$ of the mathematics doctorates, 29\% of these to women. (In Table 1 the PhDs whose citizenship was unknown at the time of the surveys appear in the All PhDs column but do not appear in the US or Non-US columns.) The percentage of new women PhDs was lowest during 1991-2000, when the rate for US citizens was higher than for non-citizens; the opposite held for men.

Marie A. Vitulli is professor emerita at the University of Oregon. Her email address is vitu11i@uoregon. edu.

For permission to reprint this article, please contact: reprint-permission@ams.org.

DOI: http://dx.doi.org/10.1090/noti1649
Table 1. PhDs Granted (Percentages of all PhDs in Two Column Citizenship Group) by Citizenship and Gender

\begin{tabular}{|c|c|c|c|c|c|c|}
\hline & \multicolumn{2}{|c|}{ US } & \multicolumn{2}{c|}{ Non-US } & \multicolumn{2}{c|}{ All PhDs } \\
\hline Period & F & M & F & M & F & M \\
\hline $\begin{array}{c}1991- \\
2000\end{array}$ & $\begin{array}{c}1350 \\
(27 \%)\end{array}$ & $\begin{array}{c}3622 \\
(73 \%)\end{array}$ & $\begin{array}{c}1147 \\
(21 \%)\end{array}$ & $\begin{array}{c}4293 \\
(79 \%)\end{array}$ & $\begin{array}{c}2597 \\
(24 \%)\end{array}$ & $\begin{array}{c}8291 \\
(76 \%)\end{array}$ \\
\hline $2001-$ & 1950 & 4531 & 2501 & 5187 & 4468 & 9761 \\
2011 & $(30 \%)$ & $(70 \%)$ & $(33 \%)$ & $(67 \%)$ & $(31 \%)$ & $(69 \%)$ \\
\hline $2012-$ & 972 & 2548 & 1357 & 2587 & 2330 & 5138 \\
2015 & $(28 \%)$ & $(72 \%)$ & $(34 \%)$ & $(66 \%)$ & $(31 \%)$ & $(69 \%)$ \\
\hline $1991-$ \\
2015
\end{tabular}

For the last 25 years the percentage of US citizen women still seeking employment has been a bit lower than that of men, though the opposite holds among non-US citizens, as shown in Table 2 . The unemployment

\footnotetext{
$\overline{{ }^{1} \text { When social scientists and statisticians study the effects of two }}$ independent variables and their interaction, they use the mathematical symbol $\times$ to denote testing for an interaction effect.

${ }^{2}$ Our full study can be found online at arXiv:1710:11256v1 [math. HO] In this summary, percentages are rounded for readability.
} 
rates were declining but increased for all categories in 2012-2015. We focused on the new PhDs who remained in the US after receiving their degrees and were still seeking employment at the time of the survey. (During 1991-2000 citizenship was unknown for some in this group, but they appear in the All PhDs column.) Following current AMS conventions on unemployment rate calculations, individuals employed outside the US as well as those whose employment status was unknown have been removed from the denominator in the calculation of the unemployment rate. We also adopt the AMS convention of removing those individuals reported as not seeking employment from the denominator. For the entire 25 years under investigation, this group accounted for $1 \%$ of all new PhDs (2\% of the females and $1 \%$ of the males). As pointed out in the 2015 survey, these conventions increase the unemployment rate from the rates reported prior to these adjustments.

Table 2. Number of New PhDs Still Seeking Employment by Citizenship and Gender (Percentages of all New PhDs in Column Cohort, denominators adjusted downward as described.)

Looking at gender $\times$ citizenship differences, Table 2

\begin{tabular}{|c|c|c|c|c|c|c|}
\hline & \multicolumn{2}{|c|}{ US } & \multicolumn{2}{c|}{ Non-US } & \multicolumn{2}{c|}{ All PhDs } \\
\hline Period & F & M & F & M & F & M \\
\hline $\begin{array}{c}1991- \\
2000\end{array}$ & $61(5 \%)$ & $271(9 \%)$ & $84(11 \%)$ & $304(11 \%)$ & $154(8 \%)$ & $595(10 \%)$ \\
\hline $\begin{array}{c}2001- \\
2011\end{array}$ & $50(3 \%)$ & $196(5 \%)$ & $89(5 \%)$ & $151(4 \%)$ & $139(4 \%)$ & $347(5 \%)$ \\
\hline $\begin{array}{c}2012- \\
2015\end{array}$ & $41(5 \%)$ & $176(8 \%)$ & $61(6 \%)$ & $85(5 \%)$ & $102(6 \%)$ & $261(7 \%)$ \\
\hline $\begin{array}{c}1991- \\
2015\end{array}$ & $152(4 \%)$ & $643(7 \%)$ & $234(7 \%)$ & $540(7 \%)$ & $395(5 \%)$ & $1203(7 \%)$ \\
\hline
\end{tabular}

shows that the disadvantage for non-US citizens from 1991-2000 is more pronounced for women; the rate for female non-US citizens was more than double the rate for citizens. The disadvantage for non-US citizen women lessened during 2001-2015. Notice that for male PhDs during 2001-2015, the unemployment rate for citizens was higher than for non-US citizens, with the greatest difference occurring in 2012-2015.

Women are less likely to have initial employment at top universities and in business and industry than men, as shown in Tables 3 and 4. In this summary we focused on pure math PhDs. The All Others rows in Tables 3 and 4 include new PhDs who accepted jobs in statistics, biostatistics, or applied math departments, outside the US, those who were still seeking or not seeking employment, as well as those whose employment status was unknown at the time of the survey. The AMS changed the annual survey reporting groupings in 2012 so we present data separately for 2012-2015. Beginning in 2012 the top-ranking Group I departments were replaced by the top-producing Public Large and Private Large departments.
Table 3. Observed Frequencies of First Jobs (Percentages of Column Cohort) for Pure Math PhDs 1991-2011

\begin{tabular}{|c|c|c|c|c|c|c|c|c|c|}
\hline & \multicolumn{3}{|c|}{$1991-2000$} & \multicolumn{3}{|c|}{$2001-2011$} & \multicolumn{3}{|c|}{ 1991-2011 } \\
\hline $\begin{array}{l}\text { Emp } \\
\text { Type }\end{array}$ & $\mathbf{F}$ & $\mathbf{M}$ & All & $\mathbf{F}$ & $\mathbf{M}$ & All & $\mathbf{F}$ & $\mathbf{M}$ & All \\
\hline Gr I & $\begin{array}{c}199 \\
(11 \%)\end{array}$ & $\begin{array}{c}849 \\
(13 \%)\end{array}$ & $\begin{array}{l}1048 \\
(13 \%)\end{array}$ & $\begin{array}{c}335 \\
(13 \%)\end{array}$ & $\begin{array}{l}1216 \\
(17 \%)\end{array}$ & $\begin{array}{l}1551 \\
(16 \%)\end{array}$ & $\begin{array}{c}534 \\
(12 \%)\end{array}$ & $\begin{array}{l}2065 \\
(15 \%)\end{array}$ & $\begin{array}{l}2599 \\
(15 \%)\end{array}$ \\
\hline Gr II & $\begin{array}{c}88 \\
(5 \%)\end{array}$ & $\begin{array}{l}326 \\
(5 \%)\end{array}$ & $\begin{array}{l}414 \\
(5 \%)\end{array}$ & $\begin{array}{l}193 \\
(8 \%)\end{array}$ & $\begin{array}{l}559 \\
(8 \%)\end{array}$ & $\begin{array}{l}752 \\
(8 \%)\end{array}$ & $\begin{array}{l}281 \\
(7 \%)\end{array}$ & $\begin{array}{l}885 \\
(7 \%)\end{array}$ & $\begin{array}{c}1166 \\
(7 \%)\end{array}$ \\
\hline Gr III & $\begin{array}{c}99 \\
(6 \%)\end{array}$ & $\begin{array}{l}251 \\
(4 \%)\end{array}$ & $\begin{array}{l}350 \\
(4 \%)\end{array}$ & $\begin{array}{l}120 \\
(5 \%)\end{array}$ & $\begin{array}{l}263 \\
(4 \%)\end{array}$ & $\begin{array}{l}383 \\
(4 \%)\end{array}$ & $\begin{array}{l}219 \\
(5 \%)\end{array}$ & $\begin{array}{l}514 \\
(4 \%)\end{array}$ & $\begin{array}{l}733 \\
(4 \%)\end{array}$ \\
\hline Masters & $\begin{array}{l}161 \\
(9 \%)\end{array}$ & $\begin{array}{l}416 \\
(7 \%)\end{array}$ & $\begin{array}{l}577 \\
(7 \%)\end{array}$ & $\begin{array}{l}202 \\
(8 \%)\end{array}$ & $\begin{array}{l}351 \\
(5 \%)\end{array}$ & $\begin{array}{l}553 \\
(6 \%)\end{array}$ & $\begin{array}{l}363 \\
(8 \%)\end{array}$ & $\begin{array}{l}767 \\
(6 \%)\end{array}$ & $\begin{array}{c}1130 \\
(6 \%)\end{array}$ \\
\hline $\begin{array}{c}\text { Bache- } \\
\text { lors }\end{array}$ & $\begin{array}{c}370 \\
(21 \%)\end{array}$ & $\begin{array}{c}787 \\
(12 \%)\end{array}$ & $\begin{array}{l}1157 \\
(14 \%)\end{array}$ & $\begin{array}{c}483 \\
(19 \%)\end{array}$ & $\begin{array}{c}877 \\
(12 \%)\end{array}$ & $\begin{array}{l}1360 \\
(14 \%)\end{array}$ & $\begin{array}{c}853 \\
(20 \%)\end{array}$ & $\begin{array}{l}1664 \\
(12 \%)\end{array}$ & $\begin{array}{l}2517 \\
(14 \%)\end{array}$ \\
\hline $2 \mathrm{Yr}$ & $\begin{array}{c}38 \\
(2 \%)\end{array}$ & $\begin{array}{l}110 \\
(2 \%)\end{array}$ & $\begin{array}{l}148 \\
(2 \%)\end{array}$ & $\begin{array}{c}61 \\
(2 \%)\end{array}$ & $\begin{array}{l}150 \\
(2 \%)\end{array}$ & $\begin{array}{l}211 \\
(2 \%)\end{array}$ & $\begin{array}{c}99 \\
(2 \%)\end{array}$ & $\begin{array}{l}260 \\
(2 \%)\end{array}$ & $\begin{array}{l}359 \\
(2 \%)\end{array}$ \\
\hline $\begin{array}{c}\text { Oth } \\
\text { Acad }\end{array}$ & $\begin{array}{c}61 \\
(3 \%)\end{array}$ & $\begin{array}{l}239 \\
(4 \%)\end{array}$ & $\begin{array}{l}300 \\
(4 \%)\end{array}$ & $\begin{array}{l}190 \\
(7 \%)\end{array}$ & $\begin{array}{l}407 \\
(6 \%)\end{array}$ & $\begin{array}{l}597 \\
(6 \%)\end{array}$ & $\begin{array}{l}251 \\
(6 \%)\end{array}$ & $\begin{array}{l}646 \\
(5 \%)\end{array}$ & $\begin{array}{l}897 \\
(5 \%)\end{array}$ \\
\hline $\begin{array}{l}\text { Res } \\
\text { Inst }\end{array}$ & $\begin{array}{c}32 \\
(2 \%)\end{array}$ & $\begin{array}{l}176 \\
(3 \%)\end{array}$ & $\begin{array}{l}208 \\
(3 \%)\end{array}$ & $\begin{array}{c}70 \\
(3 \%)\end{array}$ & $\begin{array}{l}134 \\
(2 \%)\end{array}$ & $\begin{array}{l}204 \\
(2 \%)\end{array}$ & $\begin{array}{l}102 \\
(2 \%)\end{array}$ & $\begin{array}{l}310 \\
(2 \%)\end{array}$ & $\begin{array}{l}412 \\
(2 \%)\end{array}$ \\
\hline Govt & $\begin{array}{c}36 \\
(2 \%)\end{array}$ & $\begin{array}{l}141 \\
(2 \%)\end{array}$ & $\begin{array}{l}177 \\
(2 \%)\end{array}$ & $\begin{array}{c}90 \\
(4 \%)\end{array}$ & $\begin{array}{l}202 \\
(3 \%)\end{array}$ & $\begin{array}{l}292 \\
(3 \%)\end{array}$ & $\begin{array}{l}126 \\
(3 \%)\end{array}$ & $\begin{array}{l}343 \\
(3 \%)\end{array}$ & $\begin{array}{l}469 \\
(3 \%)\end{array}$ \\
\hline $\begin{array}{l}\text { Bus/ } \\
\text { Ind }\end{array}$ & $\begin{array}{l}143 \\
(8 \%)\end{array}$ & $\begin{array}{c}754 \\
(12 \%)\end{array}$ & $\begin{array}{c}897 \\
(11 \%)\end{array}$ & $\begin{array}{l}205 \\
(8 \%)\end{array}$ & $\begin{array}{c}692 \\
(10 \%)\end{array}$ & $\begin{array}{l}897 \\
(9 \%)\end{array}$ & $\begin{array}{l}348 \\
(8 \%)\end{array}$ & $\begin{array}{l}1446 \\
(11 \%)\end{array}$ & $\begin{array}{l}1794 \\
(10 \%)\end{array}$ \\
\hline $\begin{array}{c}\text { All } \\
\text { Others }\end{array}$ & $\begin{array}{c}555 \\
(31 \%)\end{array}$ & $\begin{array}{l}2324 \\
(36 \%)\end{array}$ & $\begin{array}{l}2879 \\
(35 \%)\end{array}$ & $\begin{array}{c}602 \\
(24 \%)\end{array}$ & $\begin{array}{l}2196 \\
(31 \%)\end{array}$ & $\begin{array}{l}2798 \\
(29 \%)\end{array}$ & $\begin{array}{l}1157 \\
(27 \%)\end{array}$ & $\begin{array}{l}4520 \\
(34 \%)\end{array}$ & $\begin{array}{l}5677 \\
(32 \%)\end{array}$ \\
\hline $\begin{array}{c}\text { Grand } \\
\text { Total }\end{array}$ & $\begin{array}{c}1782 \\
(100 \%)\end{array}$ & $\begin{array}{c}6373 \\
(100 \%)\end{array}$ & $\begin{array}{c}8155 \\
(100 \%)\end{array}$ & $\begin{array}{c}2551 \\
(100 \%)\end{array}$ & $\begin{array}{c}7047 \\
(100 \%)\end{array}$ & $\begin{array}{c}9598 \\
(100 \%)\end{array}$ & $\begin{array}{c}4333 \\
(100 \%)\end{array}$ & $\begin{array}{l}13,420 \\
(100 \%)\end{array}$ & $\begin{array}{l}17,753 \\
(100 \%)\end{array}$ \\
\hline
\end{tabular}

During all periods of our study there were striking gender differences between the percentages of male and female new pure math PhDs employed in departments in which the highest mathematics degree is a bachelor's. We first refer to Table 3 for our observations. Between 1991 and 2000 the percentage of women who were employed at bachelor's-only departments was $21 \%$ vs. $12 \%$ for men; between 2001 and 2011 slightly less but still large; during 2012-2015 (Table 4), 18\% vs. 10\%, the largest relative difference we observed.

During 1991-2000 (Table 3), the percentage of women who were employed at top-ranking Group I departments was $11 \%$ vs. $13 \%$ for men; during $2001-2011,13 \%$ vs. $17 \%$ for men. To put this in perspective, during 1991-2011, $47 \%$ of all women pure math $\mathrm{PhDs}$ received degrees from Group I institutions and 56\% of the men pure math $\mathrm{PhDs}$ received degrees from Group I institutions. Looking only at Group I PhDs during 1991-2011, 24\% were women.

Similarly during 2012-2015 (Table 4) the percentage of women who were employed at Public and Private Large departments was considerably lower than for men, with the biggest difference occurring in Private Large hires. 
Table 4. Observed Frequencies of First Jobs (Percentages of Column Cohort) for Pure Math PhDs 2012-2015

\begin{tabular}{|c|c|c|c|}
\hline Employer Type & Female & Male & All \\
\hline Public Large & $\begin{array}{c}94 \\
(7 \%) \\
\end{array}$ & $\begin{array}{l}332 \\
(9 \%) \\
\end{array}$ & $\begin{array}{l}426 \\
(9 \%) \\
\end{array}$ \\
\hline Public Medium & $\begin{array}{c}60 \\
(5 \%) \\
\end{array}$ & $\begin{array}{l}179 \\
(5 \%) \\
\end{array}$ & $\begin{array}{l}239 \\
(5 \%) \\
\end{array}$ \\
\hline Public Small & $\begin{array}{c}51 \\
(4 \%) \\
\end{array}$ & $\begin{array}{l}129 \\
(4 \%) \\
\end{array}$ & $\begin{array}{l}180 \\
(4 \%)\end{array}$ \\
\hline Private Large & $\begin{array}{c}55 \\
(4 \%)\end{array}$ & $\begin{array}{l}230 \\
(7 \%)\end{array}$ & $\begin{array}{l}285 \\
(6 \%) \\
\end{array}$ \\
\hline Private Small & $\begin{array}{c}29 \\
(2 \%) \\
\end{array}$ & $\begin{array}{c}62 \\
(2 \%)\end{array}$ & $\begin{array}{c}91 \\
(2 \%)\end{array}$ \\
\hline Masters & $\begin{array}{c}53 \\
(4 \%) \\
\end{array}$ & $\begin{array}{l}121 \\
(3 \%) \\
\end{array}$ & $\begin{array}{l}174 \\
(4 \%)\end{array}$ \\
\hline Bachelors & $\begin{array}{c}222 \\
(18 \%) \\
\end{array}$ & $\begin{array}{c}354 \\
(10 \%) \\
\end{array}$ & $\begin{array}{c}576 \\
(12 \%) \\
\end{array}$ \\
\hline 2 Year & $\begin{array}{c}35 \\
(3 \%) \\
\end{array}$ & $\begin{array}{c}80 \\
(2 \%) \\
\end{array}$ & $\begin{array}{l}115 \\
(2 \%) \\
\end{array}$ \\
\hline Other Academic & $\begin{array}{c}91 \\
(7 \%) \\
\end{array}$ & $\begin{array}{l}197 \\
(6 \%) \\
\end{array}$ & $\begin{array}{l}288 \\
(6 \%) \\
\end{array}$ \\
\hline Research Inst & $\begin{array}{c}25 \\
(2 \%) \\
\end{array}$ & $\begin{array}{c}87 \\
(2 \%) \\
\end{array}$ & $\begin{array}{l}112 \\
(2 \%) \\
\end{array}$ \\
\hline Government & $\begin{array}{c}52 \\
(4 \%) \\
\end{array}$ & $\begin{array}{l}109 \\
(3 \%) \\
\end{array}$ & $\begin{array}{l}161 \\
(3 \%) \\
\end{array}$ \\
\hline Business/Industry & $\begin{array}{c}171 \\
(14 \%) \\
\end{array}$ & $\begin{array}{c}577 \\
(16 \%) \\
\end{array}$ & $\begin{array}{c}748 \\
(16 \%) \\
\end{array}$ \\
\hline All Others & $\begin{array}{c}328 \\
(26 \%) \\
\end{array}$ & $\begin{array}{r}1095 \\
(31 \%) \\
\end{array}$ & $\begin{array}{l}1423 \\
(30 \%) \\
\end{array}$ \\
\hline Grand Total & $\begin{array}{c}1266 \\
(100 \%)\end{array}$ & $\begin{array}{c}3552 \\
(100 \%)\end{array}$ & $\begin{array}{c}4818 \\
(100 \%)\end{array}$ \\
\hline
\end{tabular}

Our full study looked at the types of employment obtained by the various groups of new PhDs, not just pure mathematics PhDs.

Women are slightly less likely to be employed by departments whose ranking is at least comparable to the degree-granting department. We considered jobs at Research Institutes or Other Non-Profits as desirable and group them with the top-ranking or top-producing departments (refer to Table 5). As in past studies [3], we note that since the data collected from departments does not give detailed information on the type of position, a definitive statement is not possible. Table 5 shows that the at least comparable employment rates ${ }^{3}$ for both females and males from Group II institutions improved between 2001 and 2011.

\footnotetext{
${ }^{3}$ For each rate, we calculated the percent who obtained jobs at departments ranked at least as high as the degree-granting department or at Research Institutes/Other Non-Profits.
}

Table 5. At Least Comparable Employment Rates for New Pure Math PhDs

\begin{tabular}{|c|c|c|c|c|c|c|c|c|c|c|c|c|}
\hline \multicolumn{7}{|c|}{ PhD Granting Institution } \\
\hline \multicolumn{7}{|c|}{$1991-2011$} & \multicolumn{7}{c|}{$2001-2011$} \\
\hline Group I & \multicolumn{2}{|c|}{ Group II } & Group III & \multicolumn{2}{|c|}{ Group I } & \multicolumn{2}{|c|}{ Group II } & \multicolumn{2}{c|}{ Group III } \\
\hline F & M & F & M & F & M & F & M & F & M & F & M \\
\hline 22\% & $25 \%$ & $13 \%$ & $13 \%$ & $14 \%$ & $12 \%$ & $29 \%$ & $29 \%$ & $18 \%$ & $19 \%$ & $15 \%$ & $18 \%$ \\
\hline \multicolumn{7}{|c|}{$25 \%$} & 2012-2015 \\
\hline Public Large & Private Large & Public Medium & Public Small & Private Small \\
\hline F & M & F & M & F & M & F & M & F & M \\
\hline 22\% & $25 \%$ & $31 \%$ & $32 \%$ & $15 \%$ & $19 \%$ & $16 \%$ & $19 \%$ & $28 \%$ & $25 \%$ \\
\hline
\end{tabular}

During 1991-2000, the at least comparable employment rate for women from the top Group I programs was 3 points less than men (about 12\% less than the men's rate) while the rate for women from Group III programs was 2 points higher than the men's rate (roughly $17 \%$ higher than the men's rate). During 2001-2011, the gender difference in Group III degree recipients reversed itself and other gender differences were reduced. Between 2012 and 2015 women from Public Large programs were 12\% less likely than men to be employed by an at least comparable department, while women from Public and Private Small were about $16 \%$ and $12 \%$, respectively, more likely than men to be hired by an at least comparable department.

\section{Notes on the Data}

Each year the American Mathematical Society (AMS) conducts a census of new PhDs by sending surveys to all departments that grant doctoral degrees in mathematics, statistics, biostatistics, and applied mathematics, as well as follow-ups to all $\mathrm{PhD}$ recipients. Over the years there have been changes in what data is collected and how it is reported. Between 1991 and 2011 the AMS reported data for doctorate-granting pure mathematics departments partitioned into Groups I, II, and III, based on the then current ranking of US doctoral departments as determined by the National Research Council (NRC), a part of the National Academies of Science. Starting in 1996, Group I was subdivided into Group I Public and Group I Private and Groups IV and V were added. Group IV consisted of statistics and biostatistics programs and Group V applied mathematics and operations research programs. We exclude doctorates in operations research (Group Vb) from our current study since the AMS has not collected data on these degrees for several years.

The NRC released reports and rankings of research doctoral programs in 1982, 1995, and 2010. Prior to 2012, the AMS followed the recommendations of the Joint Data Committee to use these rankings to create three groups of 
pure mathematics doctoral programs, ${ }^{4}$ with Group I comprised of the top-rated programs. The 2010 NRC report [2] does not give a single ranking of programs but rather ranks programs on five different scales with each score presented as a range of rankings; the scales are based on 20 characteristics. Starting in 2012, upon the advice of the Joint Data Committee, the AMS partitioned the pure mathematics departments into Math Public Large, Math Public Medium, Math Public Small, Math Private Large, and Math Private Small. This subdivision was based solely on the number of $\mathrm{PhDs}$ produced by the departments as reported on the annual surveys. Lists of the departments in these groups as well as a comparison with the former groups can be found on the AMS website [1]. Due to this change, we did separate analyses for the time periods 1991-2011 and 2012-2015.

The response rate for all groups treated in this report has been very high; the 2015 Annual Survey reports that information was provided by 312 of the 318 doctoral-granting departments queried. Survey response rates by grouping are reported by the AMS in the annual surveys published in the Notices of the American Mathematical Society and available online. Despite the high overall response rate, over the past several years an increasing number of departments have sent the AMS only basic information on their new PhDs and have often omitted data on employment status. The number of unknowns would be even higher but for web searches by the AMS that secured additional employment information, especially for those in academia. This is among the reasons why the AMS conjectures new PhDs who are categorized as Unknowns are skewed toward new PhDs in non-academic employment and individuals who may no longer be in the US. The survey data also do not either distinguish between one-year and multi-year jobs or identify tenure-stream positions.

\section{References}

1. Annual Survey of the Mathematical Sciences.www.ams.org/ profession/data/annual-survey/survey-reports.

2. National Research Council. A Data-Based Assessment of Research-Doctorate Programs in the United States, 2011. The National Academies Press: Washington, DC. doi:10.17226/12994. www.nap.edu/rdp/

3. M. A. Vitulli and M. E. Flahive 1997. Are Women Getting All The Jobs? Notices Amer. Math Soc. (March 1997), www. ams .org/ notices/199703/comm-vitu11i.pdf; An Update, Notices Amer. Math. Soc. (Sept. 2010), www. ams.org/profession/ data/other-sources/Are-Women-Getting-A11-Jobs.pdf.
ACKNOWLEDGMENT. We wish to thank Thomas H. Barr and Colleen A. Rose of the American Mathematical Society for supplying the data collected from the surveys and for answering questions about the data.

\section{ABOUT THE AUTHOR}

Marie A. Vitulli's main research interests are in commutative algebra and algebraic geometry, particularly in the theories of seminormality, weak normality, and valuations on commutative rings. In 2014 she delivered the AWM-MAA Etta Z. Falconer Lecture at MAA MathFest. She created and maintains the award-winning website Women in Math Project pages . uoregon . edu/ wmnmath.

\footnotetext{
$\overline{{ }^{4} \text { When we speak of pure mathematics departments we exclude }}$ departments in applied mathematics, statistics, and biostatistics.
} 